\title{
Zonasi dan Merdeka Belajar : Kajian Kritis dari Prospektif Kebijakkan
}

\author{
Sumiana \\ ${ }^{1}$ SD Negeri Simomulyo I, Kota Surabaya, \\ *Email: anasumiana27780@gmail.com
}

Informasi Artikel
Kata kunci:
Zonasi,
Merdeka Belajar,
Kebijakan
Diterima: 12-03-2020
Disetujui: 01-05-2020
Dipubikasikan: 26-10-2020

\section{Abstrak}

Artikel ini merupakan hasil dari studi literatur terkait kebijakan baru dimana masih banyak komponen di dalamnya yang perlu dikaji secara kritis. Untuk itu penulis mengangkat judul "Zonasi dan Merdeka Belajar - Kajian Kritis dari Prospektif Kebijakan" dengan tujuan (1) dapat mendeskripsikan konsep zonasi yang sudah dilaksanakkan di Pendidikan dasar, (2) dapat mendeskripsikan konsep merdeka belajar yang sudah dilaksanakan di Pendidikan dasar, (3) dapat mendeskripsikan konsistensi atau inkonsistensi kebijakan zonasi dan kebijakan merdeka belajar di Pendidikan dasar, serta (4) mendeskripsikan rekomendasi berdasarkan analisis. Kebijakan pemeritah dalam merdeka belajar memiliki empat fokus utama dalam pendidikan antara lain; penilaian USBN komprehensif, penghapusan UN, penyederhanaan PRR, dan zonasi. Tujuan dari kebijakan pemerintah terkait program zonasi dimana untuk memeratakan pendidikan dengan asumsi tidak ada lagi sekolah favorit atau sekolah menengah kebawah. Maka secara tidak langsung selama bersekolah anak akan dekat dengan lingkungan sekolah dan lingkungan keluarga. Menindaklanjuti tujuan tersebut dapat dirujuk dari Ki Hajar Dewantara terkait Tri Pusat Pendidikan (Guru, Orang tua, dan lingkungan) dimana dalam membentuk karakter seorang anak agar dapat belajar dengan baik dan siap menghadapi masalah dibutuhkan Tripusat pendidikan (Kurniawan, 2015). Guru pertama bagi seorang anak adalah orang tua. Dimana pertama kali anak belajar bersama orang tua, mengenal segala sesuatu juga dari orang tua. Sekolah adalah tempat menuntut ilmu. Selain pelajaran dan pengetahuan yang diberikan orang tua, seorang anak juga memerlukan bimbingan pendidikan dari sekolah. Kepribadian anak juga terbentuk di sekolah, dari pergaulan disekolah, dari pelajaran yang diberikan guru. Peran masyarakat dalam pembentukan kepribadian seseorang juga memiliki andil besar. Lingkungan yang baik akan membuat seseorang memiliki kepribadian yang baik pula. Lingkungan yang buruk dapat menyebabkan seseorang memiliki kepribadian yang buruk Selain itu dengan adanya kebijakan zonasi ini menuntut guru lebih kreatif dan inovasif untuk melaksaksanakan pembelajaran, missal pembelajaran akan lebih kontekstual karena lingkungan belajar anak dekat dengan sekolah. Missal, pada pembelajaran jual beli dimana dalam tujuan penbelajaran siswa dapat mengenal pelaku ekonomi. Hal ini bisa dicontohkan secara kontekstual dengan mengaitkan materi dengan kehidupan nyata atau lingkungan sekitar siswa yang kebetulan lingkungan siswa tersebut 
berada di daerah pegunungan maka mayoritas pelaku ekonomi disana adalah petani sayur dan pedagang buah. Hal ini berbeda ketika lingkungan siswa berada di perkotaan maka pelaku ekominya adalah para pedagang fasion dan industry pabrik. Oleh karnanya salah satu tujuan pemerintah melalui kebijakan zonasi ini untuk membentuk guru, orang tua dan lingkungan dalam mendidik anak. Dengan demikian zonasi merupakan salah satu upaya pemerintah dalam membentuk Tripusat (guru, orang tua, dan lingkungan) pendidikan bagi anak.

\section{PENDAHULUAN}

Banyak sekali masalah pendidikan di Indonesia yang menitik beratkan pada kualitas pendidikan di Indonesia. Para praktisi dan akademisi mengkritik ketidak merataan kualitas pendidikan yang ada saat ini. Pada tingkat nasional di berbagai berita menyatakan tentang ketidak merataan pendidikan yang ada pada ibu kota dengan daerah 3T (tertinggal, terdepan, terluar) dengan asumsi bahwa daerah 3T menang susah dijangkau dan banyak asumsi lain yang di argumenkan. Bahkan di tingkat provinsi atau kota juga masih banyak masalah ketidak merataan kualitas pendidikan. Dari hasil nilai UN SD di dinas pendidikan kota Surabaya tercatat nilai UN tertinggi diperoleh di kawasan Surabaya Barat dan Utara dan ketika di tindak lanjuti lebih dalam kualitas pembelajaran wilayah Surabaya memang belum merata. Di beberapa sekolah menunjukkan kurang kreatifnya guru, tidak menggunakan media ketika mengajar, bahkan ada yang mengajar tanpa melakukan evaluasi pada siswanya, selain itu beberapa sekolah belum memenuhi fasilitas pendukung seperti laboratorium dan perpustakaan. Dengan adanya hal ini setiap siswa yang bersekolah di sekolah dengan kualitas pendidikan baik maka outputnya juga akan baik, sebaliknya jika siswa yang bersekolah di sekolah yang kualitas pendidikannya kurang maka outputnya juga akan kurang.

Arah kebijakan zonasi antara lain sebagai berikut: (1) terjaminnya akses pendidikan yang merata, (2) menghilangkan ekslusivitas dan diskriminasi di sekolahnya (3) kebutuhan dan distribusi guru ke sekolah akan merata (4) layanan pendidikan akan dipenuhi (5) mendorong pemda dalam pemerataan kualitas pendidikan (6) mendorong kratifitas pendidik dalam kelas hetrogen (7) meningkatkan keragaman peserta didik di suatu sekolah (8) mendekatkan lingkungan sekolah dengan peserta didik (9) mencegah penumpukan SDM berkualitas dalam suatu wilayah (10) pemerintah akan terbantu dalam memberi bantuan pendidikan dan akan lebih tepat sasaran, (Kemendikbud, 2018). Hal ini sejalan dengan pemikiran Ki Hajar Dewantara dimana tripusat pendidikan (guru, keluarga dan lingkungan) dibentuk atau dibuat untuk mendidik (afektikf, kognitif, psikomotor) anak.

Namun kenyataannya hal ini menjadi sangat konstradiktif dalam implementasinya. Kondisi psikologis peserta didik juga dipengaruhi oleh system zonasi (Nurlailiyah, 2019). Ada siswa sangat termotivasi dalam belajar agar dapat masuk ke sekolah favorit yang dituju namun hal ini menjadi masalah ketika ada ketentuan dalam system zonasi seperti jarak rumah. Sehingga siswa akan kecewa jika sudah bersungguh sungguh belajar namun hasil tidak sesuai harapan dikarenakan dampak dari suatu kebijakan. Masalah lain muncul ketika di daerah rumah siswa tersebut tidak terdapat sekolah negeri satupun sehingga tidak dapat melanjutkan sekolah di sekolah negeri 
sementara siswa tersebut tidak memiliki prestasi atau standart nilai yang ditentukan. Sebaliknya ada siswa yang di daerah rumahnya terdapat lebih dari satu sekolah negri, sekalipun siswa tersebut tidak memiliki prestasi ataupun nilai yang cukup bisa denga mudah siswa tersebut bersekolah di sekolah negeri. Selain itu guru yang biasa mengajar di sekolah favorit ketika diberlakukannya system zonasi yang menerima murid dibawah rata-rata harus mempunyai strategi ekstra dalam mengajar. Otomatis kondisi psikologis siswa maupun guru dalam kompetensinya akan terpengaruh dengan adanya system zonasi.

\section{METODE}

Artikel ini menggunakan studi literature, dimana analisis, diskusi, sari informasi dan penyusunan dilakukan dari mengkaji hasil teori-teori buku, artikel, pembelajaran, hasil penelitian, serta undang-undang atau aturan yang berlaku, menurut Danial dan Warsiah dalam (Nurul Hidayah, Sulfahmi Sulfahmi, Iani Zairani, Marwah Yusuf, 2019), Pada artikel ini ada ketentuan dalam pencarian sumber informasi, seperti minimal sepuluh jurnal internasional, lima jurnal nasional, dan tiga jurnal afiliasi Universitas Negeri Malang, sebagai pertimbangan untuk memperdalam kajian pada artikel ini.

\section{HASIL DAN PEMBAHASAN}

\section{Konsep zonasi}

Melalui kebijakan zonasi Peta Mutu Pendidikan dan Solusi Terapinya (PMP-ST) disusun dengan tujuan Memberikan gambaran tentang data capaian/pemenuhan Standar Nasional Pendidikan (SNP) pada tingkat satuan pendidikan (Sumiati, 2020). Menurut Kemendikkbud, PPDB pada system zonasi memiliki ketentuan tersendiri seperti, calon peserta didik harus memiliki identitas domisili yang beradius zona terdekat. Implementasi PPDB melalui system zonasi berlangsung dengan cukup transparan, objektif dan akuntable (Kemendikbud, 2018).

Menurut Colemen, konsep kesetaraan dalam pendidikan antara lain dapat memberikan pendidikan gratis samapai tingkat tertentu (Coleman, 1968). Selanjutnya pada penelitian (Tali Tal, 2004) yang berjudul Community-based environmental educationĐa case study of teacher parent collaboration, menyatakan bahwa EF (pendidikan lingkungan) mendorong penggabungan konten lokal ke dalam kurikulum, dan pembentukan model pengajaran alternative dimana membutuhkan peran guru, keluarga, dan lingkungan. Pendapat lain (Firdausi et al., 2019) menyatakan bahwa untuk membentuk ketrampilan anak orang tua memiliki peran dalam mendidik. Sementara itu (Ramli et al., 2016) menyatakan, sesuai dengan kompetendi pedagogic yang dimiliki guru maka merencanakan, melaksanakan dan mengvaluasi merupakan tuntutan guru.

Berdasarkan pendapat diatas bahwa kosep dari zonasi adalah untuk menciptakan pemerataan kualitas pendidikan dan menghapuskan sekolah favorit dikalangan msyarakat. Namun terdapat banyak pro dan kontra pada pelaksanaannya salah satunya dimana banyak siswa yang mendadak pindah domisili hanya agar bisa bersekolah di sekolah yang favorit. Dari kebijakkan pemerintah dan masalah yang ada konsep zonasi sendiri 
malah menjadi paradox kebijakan dimana tujuan pemerintah untuk memeratakan pendidikan dan menghapuskan sekolah favorit namun bertentangan dengan pelaksanaannya. Stone (2012) mengatakan, dalam pembuatan kebijakan masalah yang timbul tidak hanya dari luar kelompok, melainkan bisa dari dalam kelompok (aktor pembuat kebijakan). Dimana masih banyak calon siswa yang memburu sekolah favorit tersebut dengan berbagai cara. Selain itu pada penerapannya ketika calon siswa itu sebenarnya memiliki nilai UN cukup tinggi namun karena jarak rumah dan sekolah negeri yang ada tidak memenuhi radius hingga akhirnya siswa tersebut tidak bisa bersekolah di sekolah negeri. Maka yang tujuan awal kebijakan pemerintah untuk memeratakan mendidikan malah menjadi beban masyarakat dalam memperoleh pendidikan.

\section{Konsep merdeka belajar}

Merdeka dapat di artikan bebas, yang dimaksud bebas yakni tidak memiliki kendala atau bebas dari penjajah. Seperti contoh: Indonesia merdaka pada tanggal 17 Agustus 1945. Arti lain dari merdeka adalag lepas dari tuntutan. Seperti; merdeka dari penjara. Merdeka juga bisa diartikan tidak memiliki keterikatan atau ketergantungan pada orang atau pihak tertentu, (KBBI, 2019).

Sementara itu belajar memiliki banyak arti. Perubahan kepribadian manusia ditunjukkan melalui kualitas dan kuantitas perbuatan, perubahan tersebutlah yang dinamakan belajar (Pane \& Darwis Dasopang, 2017). Perlu digaris bawahi dalam pernyataan diatas dimana peningkatan kuaitas dan kuantitas terlihat dari perubahan prilaku maka ketika seseorang setelah melaksanakan proses belajar namun tidak ada perubahan tingkah laku maka ada dua kemungkinan, pertama mungkin seseorang tersebut tidak belajar sungguh-sungguh, yang kedua proses belajarnya dinyatakan gagal.

(Gustafson-Pearce \& Grant, 2015) mempertimbangkan bagaimana pendidik dan industri dapat memanfaatkan alat dan sistem media ini, untuk memungkinkan keterlibatan dan transfer pengetahuan antar pihak. Sementara itu (Tchamyou, 2020), pembelajaran seumur hidup dipahami dan diukur sebagai gabungan pengetahuan yang diperoleh dari pendidikan dasar hingga pendidikan tinggi. Dengan kata lain merdeka belajar dimaksudkan bahwa siswa bisa belajar dimana saja dan kapan saja tidak terbatas oleh ruang dan waktu. Seperti saat ini ketika dunia pendidikan dan seluruh komponen didalamnya sedang menghadapi pademi cobid-19 membuktikan bahwa proses pembelajaran harus tetap berjalan. Dengan kecanggihak teknologi berbagai aplikasi sudah bisa digunakan. Berbagai informasi bisa diperoleh. Hal ini sejalan dengan pendapat Ki Hajar Dewantara tentang konsep tiga dinding.

Maka dapat disimpulkan bahwa bahwa merdeka belajar dapat dikatakan bebas dalam belajar. Dan perlu dipertegas bahwa bebas disini bukan berarti sesuka hati atau seenaknya yang bisa bolos sekolah atau tidak mengerjakan PR namun lebih pada suasana belajar yang bahagia dan menyenangkan. Karena selama ini ketika seorang anak dituntut untuk memperoleh nilai bagus, patuh pada guru, memperoleh nilai tinggi dan ber akademik bagus, dan ketika anak itu atau anak lain didak bisa melakukan hal tersebut maka untuk berangkat ke sekolah saja mereka merasa akan berangkat ke penjera. Guru, sekolah, pelajaran merupakan momok bagi 
mereka yang tidak bisa melaksanakan tuntutan tersebut. Merujuk dari buku Tut Wuri Handayani, Ki Hajar Dewantara dalam ("Reveal. 'Tut Wuri Handayani' - A Student-Centred Learn. Approach- by Ki Hajar Dewantara from Early 20th Century A Lit. Rev.," 2016), bahwa taman adalah tempat yang nyaman untuk bermain dan belajar bukan untuk membuat anak menjadi takut, maka sekolah adalah taman.

Suasana belajar yang menyenangkan dan tidak menakutkan merupakan konsep dari merdeka belajar itu sendiri dimana menciptakan suasana belajar yang membahagiakan tanpa membebani siswa dengan tuntutan skor yang harus dicapai (Mustaghfiroh, 2020). Dengan demikian konsep kebijakan pemerintah dalam merdeka belajar yang didasarkan dari beberapa teori memiliki tujuan kuat bahwa belajar tidak terbatas pada ruang kelas, belajar juga tidak lagi dijadikan momok bagi siswa melainkah hal yang menyenangkan, menggembirakan dengan harapan segala karakter dan proses belajar dapat diterima siswa dengan baik dan tercapai.

Hal tersebut juga harus di imbangi oleh peran serta guru karena pada implenemtasi kebijakan banyak guru yang menyalah gunakan atau missundertanding dengan konsep merdeka belajar. Kenyataannya banyak guru yang dalam proses mengajar hanya memberikan tugas dan mengumpulkannya tanpa menindalkanjuti, banyak guru yang akhirnya tidak mempersiapkan pembelajaran sehingga mengajar tanpa menggunakan media atau komponen pembelajaran yang ideal. Banyak guru yang tidak mau membuat RPP lagi sekalipun hanya satu lembar. Kasus tersebut terjadi dengan mengatas namakan merdeka belajar atau mungkin merdeka mengajar. Padahal RPP dan komponen lain dalam pembelajaran merupakan suatu kualitas guru dalam mengajar. Setiap proses pembelajaran memerlukan suatu perencanaan yang harus diramcang oleh guru untuk mencapai tujuan pembelajaran yang sudah ditetapkan. Ketika guru merasa terbebani atau keberatan maka perlu dipertanyakan kualitas guru tersebut. RPP dan komponen lain dalam pembelajaran bukanlah bagian dari administrasi guru melainkan bagian dari kualitas guru dalam mengajar. Sehingga dengan adanya kebijakan merdeka belajar yang dikeluarkan oleh pemerintah hendaknya di ikuti dengan sosialisasi atau persiapan matang agar hingga pada implementasinya sesuai dengan konsep awal kebijakan itu sendri.

\section{Analisis konsistensi atau inkonsistensi kebijakan zonasi dan kebijakan merdeka belajar di pendidikan dasar berdasarkan studi literatur}

UUD 1945 pasal 31 yang berbunyi bahwa setiap warga Negara memiliki hak untuk memperoleh pendidikan (UUD 45, 1945). Selanjutnya data dari (Kemendikbud, 2019) bahwa Angka Partisipasi Kasar (APK) dan Angka Partisipasi Murni (APM) menunjukkan peningkatan. APK SD mencapai 106,44\% yang di ikuti APM 93,73\%. Merujuk dari uraian diatas sudah sangat jelas bahwa setiap warga Negara Indonesia berhak untuk memperoleh pendidikan. Ketettapan UU No.14 Tahun 2018 tentang diterapkannya system zonasi menjadi paradox kebijakan dengan asumsi bahwa setiap anak berhak memperoleh pendidikan tetapi terbatas dengan ketentuan kebijakan zonazi.

Menurut (Skrtic, 1991), Paradox jika fokus pada kebijakan, praktik, dan asumsi landasannya saling bertentangan. Pendapat lain (Mee, 2007) mengemukakan suatu kebijakan yang bertentangan juga bisa dikatakan 
suatu paradox. Sementara itu (Zwanzig et al., 1992) menyatakan Paradoks adalah keadaan terlipat asli dengan pencarian acak di antara semua konfigurasi yang mungkin dapat memakan waktu sangat lama. Selanjutnya (Kraut et al., 2002) menyebut efek sebagai "paradoks" . Dari beberapa pendapat diatas dapat ditarik garis besar bahwa kebijakan zonasi di Indonesia yang sudah berlangsung saat ini menjadi paradox antara kebijakan yang ditetapkan dengan implementasinya dan juga kebijakan yang telah ditetapkan dengan kebijakan lain yang tujuannya sama.

\section{Rekomendasi berdasarkan hasil analisis}

Terkait dengan program zonasi dengan berbagai permasalahan yang muncul dalam implementasinya sehingga menjadi paradox. Dimana paradox terjadi antara kebijakan yang ada dengan kebijakan yang baru serta kebijakan yang baru dengan implementasinya maka setiap warga negara yang hendak bersekolah di sekolah yang akan dituju mengikuti aturan kebijakan program zonasi, seperti jarak rumah, surat domisili dan lain sebagainya. Selain itu masih banyak yang perlu direvitalisasi terkait kebijakan yang sudah ada dengan kebijakan yang baru mengingat memiliki satu tujuan yang sama yaitu menceerdaskan anak bangsa. Maka hal pertama yang dapat dilakukan yaitu, mempersiapkan sekolah negeri diberbagai wilayah minimal satu sekolah negeri di suatu kelurahan tujuannya untuk mempermudah peserta didik yang hendak memperoleh pendidikan. Selanjutnya berlandaskan pemerataan kualitas pendidikan maka kualitas guru juga perlu di tinjau baik kompetensi dan gelar akademik dalam mengajar. Hal lain yang dapat dilakukan yakni pemerataan guru, guru yang berkompeten tidak selalu diletakkandi sekolah dengan mayoritas guru berkompeten juga. Beberapa langkah diatas bisa dilaksakan oleh pemerintah mungkin pada lingkup kota jika lingkup nasional belum terjangkau. Ketika hasil dari lingkup kota tersebut terlihat bisa dibuat percontohan untuk lingkup nasional.

\section{KESIMPULAN}

Dari hasil uraian pembahasan diatas dapat ditarik keimpulan bahwa dengan mengatasnamakan pemertaan kualitas pendidikan terwujudlah kebijakan zonasi. Dimana sekolah dalam menerima siswa baru memiliki ketentuan ketentuan yang terkait dengan jarak rumah dan domsili, konsep merdeka belajar dapat diartikan sebagai proses pembelajaran yang bebas. Dimana bebas tidak berarti semaunya melainkan bebas dalam memperoleh informasi dalam pembelajaran serta siswa tidak lagi dibebani oleh nilai-nilai atau tuntutan akademik. Sejauh kebijakan zonasi ini ditetapkan, ketentuan dari kebijakan ini konsisten diterapkan karena dalam penerapannya menggunakan system. Namun kesiapan dan ketentuan kebijakan zonasi ini menjadi inkonsisten karena antara ketentuan kebijakan dan implementasinya belum sejalan sehingga menjadi paradox kebijakan. Berikut beberapa rekomendasi yang dapat dijadikan langkah solusi pada masalah kebijakan yang muncul. Melalui landasan UUD 45 pasal 31 dimana setiap warga Negara Indonesia memiliki hak 
untuk mendapatkan pendidikan maka untuk keterlaksaan kebijakan program zonasi ini masih perlu pembenahan, seperti mempersiapkan sekolah negeri diberbagai wilayah minimal satu sekolah negeri di suatu kelurahan tujuannya untuk mempermudah peserta didik yang hendak memperoleh pendidikan,selanjutnya berlandaskan pemerataan kualitas pendidikan maka kualitas guru juga perlu di tinjau baik kompetensi dan gelar akademik dalam mengajar, Hal lain yang dapat dilakukan yakni pemerataan guru, guru yang berkompeten tidak selalu diletakkandi sekolah dengan mayoritas guru berkompeten juga, beberapa langkah diatas bisa dilaksakan oleh pemerintah pada lingkup kota jika lingkup nasional belum terjangkau. Ketika hasil dari lingkup kota tersebut terlihat bisa dibuat percontohan untuk lingkup nasional.

\section{DAFTAR PUSTAKA}

Coleman, J. (1968). The Concept of Equality of Educational Opportunity. Harvard Educational Review. https://doi.org/10.17763/haer.38.1.m3770776577415m2

Firdausi, T., Rahmawati, R. D., \& Ekayani, D. (2019). Peran Orang Tua sebagai Pendidik dalam Keterampilan Berbicara Anak Usia SD dari Komunitas Sedulur Sikep. Sekolah Dasar: Kajian Teori Dan Praktik Pendidikan. https://doi.org/10.17977/um009v28112019p055

Gustafson-Pearce, O., \& Grant, S. B. (2015). The Use of Virtual Environments for Knowledge Sharing in Distance Learning Education, with a View to Informing Industry. International Journal of Knowledge and Systems Science. https://doi.org/10.4018/ijkss.2015070103

KBBI. (2019). KBBI - Kamus Besar Bahasa Indonesia. Kamus Besar Bahasa Indonesia.

Kemendikbud. (2018). Sistem Zonasi Strategi Pemerataan Pendidikan yang Bermutu dan Berkeadilan. Web. http://publikasi.data.kemdikbud.go.id/uploadDir/isi_BF0CF9C3-2C2B-4A54-97342CB8BB80470B_.pdf

Kemendikbud. (2019). Statistik Persekolahan SMK 2018-2019. In Setjen, Kemendikbud.

Kraut, R., Kiesler, S., Boneva, B., Cummings, J., Helgeson, V., \& Crawford, A. (2002). Internet paradox revisited. Journal of Social Issues. https:// doi.org/10.1111/1540-4560.00248

Kurniawan, M. I. (2015). Tri Pusat Pendidikan Sebagai Sarana Pendidikan Karakter Anak Sekolah Dasar. PEDAGOGLA: Jurnal Pendidikan. https://doi.org/10.21070/pedagogia.v4i1.71

Mee, A. (2007). E-learning funding for schools: A policy paradox? In British Journal of Educational Technology. https://doi.org/10.1111/j.1467-8535.2006.00596.x

Mustaghfiroh, S. (2020). Konsep "Merdeka Belajar” Perspektif Aliran Progresivisme John Dewey. Jurnal Studi Guru Dan Pembelajaran. https://doi.org/10.30605/jsgp.3.1.2020.248

Nurlailiyah, A. (2019). Analisis kebijakan sistem zonasi terhadap perilaku siswa SMP di Yogyakarta. Realita.

Nurul Hidayah, Sulfahmi Sulfahmi, Iani Zairani, Marwah Yusuf, S. S. (2019). COMBINE ASSURANCE DALAM KONTEKS PENGENDALIAN. Jurnal Ilmiah Ekonomi, Manajeman , Dan Akutansi, 08(02).

Pane, A., \& Darwis Dasopang, M. (2017). BELAJAR DAN PEMBELAJARAN. FITRAH:Jumal Kajian IlmuIlmu Keislaman. https://doi.org/10.24952/ fitrah.v3i2.945

Ramli, M., Dasar, P., \& Malang, P. N. (2016). Peran Kompetensi Pedagogik Guru Dalam Pembelajaran Tematik Di Sekolah Dasar. Peran Kompetensi Pedagogik. Guru Dalam Pembelajaran Tematik. Di Sekolah Dasar.

Revealing "Tut Wuri Handayani” - A Student-Centred Learning Approach- by Ki Hajar Dewantara from The Early 20th Century: A Literature Review. (2016). Revealing "Tut Wuri Handayani" - A Student-Centred Learning Approach- by Ki Hajar Dewantara from The Early 20th Century: A Literature Review. https://doi.org/10.22146/jpki.25295

Skrtic, T. (1991). The Special Education Paradox: Equity as the Way to Excellence. Harvard Educational Review. https://doi.org/10.17763/haer.61.2.0q702751580h0617 
Sumiati, T. (2020). Pemetaan Mutu Pendidikan Dan Solusi Terapinya (PMP-St) Jenjang Sma Di Wilayah Kota Palangkaraya. PEDAGOGIK: JURNAL PENDIDIKAN, 15(1). https://doi.org/https://doi.org/10.33084/pedagogik.v15i1.1303

Tali Tal, R. (2004). Community-based environmental education-a case study of teacher-parent collaboration. Environmental Education Research. https:/ / doi.org/10.1080/1350462042000291047

Tchamyou, V. S. (2020). Education, lifelong learning, inequality and financial access: evidence from African countries. Contemporary Social Science. https://doi.org/10.1080/21582041.2018.1433314

UUD 45. (1945). Undang-undang Dasar RI Tahun 1945. Departemen Kesehatan RI.

Zwanzig, R., Szabo, A., \& Bagchi, B. (1992). Levinthal's paradox. Proceedings of the National Academy of Sciences of the United States of America. https://doi.org/10.1073/pnas.89.1.20 